\title{
War Injuries: A Retrospective study of the Iran-Iraq War
}

\author{
Mohammad Zarei, Amir Reza Farhood, Mahmud Farzan, Mohammad Javad Dehghani Firoozabadi*, Furqan MY \\ Khan
}

Department of Orthopedics, Iran

*Corresponding author: Mohammad Javad Dehghani Firoozabadi, Department of Orthopedics, Iran

Submission: 眥 September 26, 2018; Published: 眥 October 30, 2018

\begin{abstract}
Warfare is massive destruction of human life and infrastructure. A single war can catapult a nation many years back from its current state. Wide scale trauma is gigantic problem to deal with and as latest war trends are towards targeting more civilians there are huge number of civilian casualties apart from injured military personals. Injuries in war are multifactorial depending mostly on arms engaged.

In this retrospective study, we studied of 8437 war injured people who were transported and treated in Imam Khomeini hospital, Tehran between 1980 and 1988. 7352 were physically injured 67\% had extremity injuries with mean age of 23 years. 36\% had upper extremity injury and 64\% lower extremity. Regarding the causes of fractures, mortar and cannon trauma were the highest cause of fracture $54 \%$. $37.7 \%$ had infection of fracture site, $17.1 \%$ had vascular lesions and $20.4 \%$ had nerve injuries with fractures. Also, among the injured, $15 \%$ were amputation cases.

Trauma is one of the major health problems in countries that have already or are currently engaged in war. Extremity injuries as it is one of the most common traumata in war were considered in our study. The important principle is recognizing injury types, ways of treating and preventing further complications.
\end{abstract}

Keywords: Warfare; Trauma management; Extremity injuries

\section{Introduction}

Warfare is massive destruction of human life and infrastructure. A single war can catapult a nation many years back from its current state. Wide scale trauma is gigantic problem to deal with and injuries in war are multifactorial depending mostly on arms used. There is no exact stats available about the civilian mortality and morbidity in war, previous studies suggest that about 30-65 $\%$ of total injuries and deaths in wars are civilians. Although, as latest war trends are towards targeting more civilians there are huge number of civilian casualties apart from injured military personals [1]. Notably mechanism of injury is different in civilians as compared to military and the part of the body involved is diverse [2]. War injuries are generally by two mechanisms, one resulting from collision of projectiles such as bullets to the body and other being fragmentation munitions of explosive ordnance such as mines, grenades, mortars and bombs $[3,4]$. Various factors affect the damage caused by a projectile, including the velocity of the projectile, the type of weapon used and the physical characteristics of hit texture [5]. In addition, depth and type of injuries caused are not the same in different anatomical areas and may lead to immediate or delayed death or disability in person. The war between Iran and Iraq is one of the longest wars of the twentieth century that lasted for 8 years leaving more than one million people dead or wounded [6]. Several studies have been undertaken to discuss the type of damage to the injured in the Iran-Iraq war, including military [7]. One of these studies was that of Mr. Mohebbi et al. [7] that was carried out on medical documents of 1000 war wounded individuals reported by Supreme Medical Commission. Extremity injuries are major concerned trauma in war for both military and civilians. In the case of trauma to military personals involved in war, $85-88 \%$ are combat wounds and this percentage is much lower in civilians of about $20-23 \%$ [8]. In a study that has been conducted in Iran on the injured of Iran-Iraq war, $54.4 \%$ sustained trauma to extremities [9]. This study aims to examine the volume, mechanism and complications of extremity trauma and compare it with other largescale wars that took place previously.

\section{Method}

This retrospective study was carried on documents of 8437 war injured people who were transported and treated between 1980 and 1988 in Imam Khomeini hospital in Tehran, 7352 of them had physical injuries. Transmission of information to the data collection form was carried out by studying the records of these people. Data collection form included the type of injury, age of injured, mechanism of injury, location of injury, associated lesions, and the treatment given. After collection, data was used for 
the analysis of indicators such as frequency and mean. All analyzes were conducted by using the SPSS software.

\section{Result}

During the 8 years of war between Iran and Iraq, 7352 patients were hospitalized in Imam Khomeini Hospital, Tehran with physical injuries (shrapnel, bullets, accidents, etc.). 4926 of them had extremity injuries $(67 \%)$ and 4759 of them were male $(96.6 \%)$ and 167 were female (3.4\%). All aged between 14 to 48 years and most cases of injured were in the range of 21 to 25 years by mean of 23 . There were 4926 patients with 6601 injuries as some had multiple injuries. Regarding the kind of trauma out of 6601, 4885 was due to shrapnel (74\%), 792 was due to bullets (12\%) and about 924 injuries was due to different traumas such as accidents, debris, etc. (14\%). About the injurie's location, 2376 (36\%) of them was in the upper extremity, $13 \%$ in proximal and $23 \%$ in distal. Other 64\% were related to lower extremities $39 \%$ Proximal and $25 \%$ distal. There were 3489 fractures reported among the 6601 injuries (53\%) that the frequency and percentage of every bone involved has been mentioned which femur has been the most common bone injured with $20 \%$ rate of fracture.

Some of the cases with articular fractures were treated with arthroplasty, 88. Mostly of the knee joint (43.2\%) and then the hip $(27.3 \%)$ and the elbow (22.7\%) and shoulder (6.8\%). Among the 1394 fixation cases, 1082 cases were internal (77.6\%) and 312 were external fixation (22.4\%).

Among the 6601 injured limb, 1359 cases of arterial lesions were observed (20.6\%). The most case of severed artery was the superficial femoral (40\%) and then popliteal (22\%). 216 amputations were done among the 627 cases of severed artery $(34.4 \%)$ that in most cases amputations were performed due to injury of popliteal artery or superficial femoral (118 cases). The most common site of pseudo aneurysm formation was noted to be at superficial femoral artery (164 cases) and the most common site of arteriovenous fistula formation was femoral artery (64 cases). Type and percentage of treatment carried out in these vascular lesions.

There were 600 cases of fractures with vascular injury (44.2\%) and 201 cases of fractures were reported accompanying nerve damage $(14.8 \%)$. In total there were reports of 2112 cases of nerve damage which is about $32 \%$ of entire injuries. A Thorough history, examination, description of surgery and results of EMGNCV of these patients were recorded. In respect to kind of lesion to the nerve, $13 \%$ were complete amputations (Neurotmesis), $48 \%$ incomplete amputations (Axonotmesis), 16\% compressive lesions (Neurapraxia) and other $23 \%$ were uncertain. Ulnar and Sciatic nerve were most commonly injured, $21 \%$ each.

Location of nerve injuries in upper and lower limb is shown in Tables $1 \& 2$. The elapsed time between nerve injury and surgical intervention ranges from 1.5 months to maximum of 4 years. Among all the injuries, $40 \%$ of the wounds were reported to be infected with microorganisms such as Staphylococcus and Clostridia and was treated with antibiotics mostly ampicillin and cefazolin.
Table 1: Location and frequency of nerve injury in the upper limb.

\begin{tabular}{|c|c|c|c|c|}
\hline Axilla & Arm & Elbow & Wrist & \\
\hline 82 & - & 271 & 221 & Ulnar \\
\hline 63 & - & 82 & 265 & Median \\
\hline 44 & 165 & 89 & - & Radial \\
\hline
\end{tabular}

Table 2: Location and frequency of nerve injury in the lower limb.

\begin{tabular}{|c|c|c|c|}
\hline Pelvis & Thigh & Blow Knee & \\
\hline 376 & 144 & - & Sciatic \\
\hline- & 197 & - & Peroneal \\
\hline- & 32 & 101 & Tibial \\
\hline
\end{tabular}

\section{Discussion}

Studies on extent of war injuries are important to countries that are currently at war, specifically civil war or countries that previously engaged in battle or even to countries that are not currently engaged in war but are in potential conflict. Appropriate planning to manage the injuries in war should be of outmost importance, if it can be executed in proper method the chaos can be minimized and lessen the huge economic burden of the country. Injuries in war depends mainly on type of war being fought and on type of military equipment used. Injuries sustained by civilians in urban warfare as could be from civil war are very different from injuries sustained by military personals fighting in war zones. For example, in the study conducted by Mr. Erhan Er [8] on the Syrian civil war injuries, $18 \%$ of injured were children and head injuries were the most common type of injury in children but in adults, it was extremity and abdominal injuries. Total of $23.3 \%$ extremity injury was reported in his study but the most common cause death due to trauma was reported as head injury (42.5\%). This study report the nature of civil wars fought in urban areas making civilians vulnerable mostly children and women. The war between Iran and Iraq is considered one of the longest war of the twentieth century that was associated with huge damages for both countries. However, after more than 27 years after the war thousands of people are still suffering from disabilities in both countries which requires a extensive study to examine the types of injuries, its complications and treatment applied for these injuries. In all wars, injuries related to extremities covers a large percentage of war injuries. In the study we've done, $67 \%$ had extremity injuries that the most effected were in range of 21-35 years which shows the fact that manpower in war have such significant role and youth were huge source in terms of physical fitness. In another study conducted in Iran, $75 \%$ of those injured were in the age range of 15 to 24 years with a mean age of $21.9 .54 .5 \%$ had extremity injuries $24 \%$ in upper extremity and $30.5 \%$ in lower extremity. In the war of Croatia Stanjner \& Petr [10], Harris et al. [11] 83\% of extremity injury were reported. In the study of Mr. Lynn G et al in 2008 which was related to America's 
war in Iraq and Afghanistan, 70.5\% of those injured were extremity trauma. [12]. But in another study, again related to American military in the Iraq war, 54\% extremity injury were reported [9]. In the same study, the rate of extremity injury in American war with Korea was 65\%, [13] and in Vietnam war was 61\% (Hardaway $3^{\text {rd }}$ 1978) and in the Second World War extremity trauma was reported to be $71 \%$ of all injuries [14]. As rate of trauma to extremity in all wars are high being more than $50 \%$, it is necessary to have clear plan of management specifically for extremity trauma in case of such events. According to Table 3 rate of lower extremity injury in most wars have been reported higher than the upper extremity. In addition, this table compares extremity fractures of Iran-Iraq was with other wars.

Table 3: Compare the distribution of fractures and extremity injury in other wars.

\begin{tabular}{|c|c|c|c|c|c|c|}
\hline $\begin{array}{l}\text { Current } \\
\text { Study }\end{array}$ & USA-Vietnam & Iraq-USA & Iran-Iraq & Korea-USA & WWII & \\
\hline 53 & 27 & 26 & & 23 & & Fracture \\
\hline 24 & 27 & 28 & 24 & 29 & 23 & $\begin{array}{l}\text { Upper extremity } \\
\text { injury }\end{array}$ \\
\hline 43 & 34 & 26 & 30.5 & 36 & 48 & $\begin{array}{l}\text { Lower extremity } \\
\text { injury }\end{array}$ \\
\hline 67 & 61 & 54 & 54.5 & 65 & 71 & $\begin{array}{l}\text { Total extremity } \\
\text { injury }\end{array}$ \\
\hline
\end{tabular}

There are different statics on rate of fractures in war. In our study, 53\% of extremity trauma had fractures, that doesn't have much difference $(54.5 \%)$ compared with another study on same war [7]. But the rate of fractures in this study is much more than America wars with Korea [13], Vietnam (Hardaway $3^{\text {rd }}$ 1978), World War II [14] and Iraq- Afghanistan [9] and is less than what is reported in the study related to injured people of German war [15] with $86 \%$ of fracture rate. In addition to bone fractures, Joint damage including dislocation may also occur in a number of war injured. In this study, the most injured joint, was knee (30.4\%). In addition, study conducted by Golestanha et al. in 2008 on IranIraq war as well conclude that most injured joint was knee joint (31.3\%). In the upper extremity most injured joint is reported to be interphalangeal joint, 10.8 .

Trauma to extremity may have complications such as nerve damage, vascular injury, infections leading amputation. In our study, the amount of amputation was $15 \%$. In a study conducted in 2008 by Mr. et al Lynn G, the amount of amputation in America's war with Iraq and Afghanistan reported to be merely $9.6 \%$ of major extremity injuries. $7.5 \%$ amputations was related to lower extremities and $2.1 \%$ to upper extremities. The most reported type of amputation has been BKA. In this same study the rate of amputation during the Vietnam-America War was $8.3 \%$. Our study report that the rate amputation in Iran-Iraq war was higher than other wars. Lynn $\mathrm{G}$ et al investigated the mechanisms of injury in war leading amputations, they reported that $87.9 \%$ amputations were related to explosion devices, $6.2 \%$ due to MVC and in rest $4.7 \%$ amputations were due various other causes.

Further major complications of trauma to extremity is nerve damage and vascular injury. A study was done based on report of EMG-NCV on wounded population in which $30 \%$ of injuries has been nerve lesion, mostly of the Axonotmesis (48\%) and the most involved nerve was ulnar. $20.6 \%$ cases of extremity injuries are associated with vascular involvement as well and the most involved artery was superficial femoral. In study on American war in Iraq and Afghanistan the extent of neurvascluar injury was reported to lower than our study, in upper extremities it have been reported $15.9 \%$ and $14.9 \%$ for lower extremities [12]. The difference in statics of these two studies could be related to different military equipment used and military logistics. Trauma in war hugely depends on kind of weapons used and branch of military the personals are serving. In a study of Mr. et al Howard R in 2003, the distribution of various combat injury mechanisms in the various military branches have been examined [16], the difference can be seen in Table 4 .

Table 4: Distribution of various combat injury mechanisms in the various military branches.

\begin{tabular}{|c|c|c|c|c|}
\hline Air & Sea & Armor & Infantry & \\
\hline 5 & 25 & 50 & 90 & Ballistic \\
\hline 50 & 10 & 5 & $3-F e b$ & Blunt \\
\hline$<5$ & 10 & 5 & $3-F e b$ & blast \\
\hline 25 & 30 & 25 & $3-F e b$ & Thermal \\
\hline 10 & 25 & 15 & $<5$ & combined \\
\hline
\end{tabular}

In the same study $[16,17]$ the mechanisms that totally lead to individual's damage has been reported as follows: fragment injury $(62 \%)$, bullet $(23 \%)$, burn (6\%), blast injury $(3 \%)$ and other (6\%). In addition, the difference between the primary site of injury and a part of bodily harm causing death was investigated. 
Large percentage of trauma was in soft tissue and extremity (47\% and $26 \%$ ) But the most causes of death was due to head injury (37\%) and chest (24\%) [16]. This finding suggests that however, extremity injury and soft tissue are seen in a higher percentage of wounded soldiers and leaves a lot of morbidity but if appropriate care and timely assistance is provided it had low risk of death. This issue is intriguingly important. In the sense that if planned properly and according to the existing facilities, a large number of war wounded could be treated properly at an early stage and can reduce further damage and complications leading death. For example, in the case of extremity injury in war, life can be can saved by preventing bleeding with primary actions such as wound dressing and packing. In addition, the initial irrigation and dressing of the wound and starting appropriate antibiotics reduces the potential risk of infection. If there is a fracture, immobilizing the extremities with splints and initiating early fracture care such as ice pack and limb elevation can relieve pain and reduce the incidence of compartment syndrome. According to a study on America's war in Iraq, approximately 30-50 general surgeons and 10-15 orthopedic were in the war zone [17-19]. Although, all these surgeons were not performing major surgeries in war zone, but certainly early action in stabilizing wounded lead to reduce morbidity and mortality in these individuals. However, conducting studies on warfare are matter of outmost difficulty as many of times collecting untampered data from such events is not possible.

\section{Conclusion}

Collateral warfare damage is one of the major concern in respect of both economical and health issues in countries that were previously at war or currently engaged in conflict. As of current state more and more countries are engulfed in potential conflicts and possibility of was in near future. Therefore, understanding types and frequency of injuries, mechanism of injury and factors influencing trauma is of extreme importance in appropriate management. Trauma to extremity is the most common war injury reported in the literature and by appropriate timely management extent of such trauma can be well controlled. Trauma and war wounded, if not managed in proper planned manner can create chaos in the country leading to increased morbidity, wide spread infections, amputation and complications such as fracture nonunion and a neurovascular injuries and even high rate of mortality. However, planning might differ for every country which is at war and is unique to that country, considering its economic status, health facilities, divisions of military engaged and the type of weapons used. Nevertheless the most important step is recognizing injuries, management and preventing further complications which necessitates extensive studies on injuries of war.

\section{References}

1. Meddings DR (2001) Civilians and war: A review and historical overview of the involvement of non-combatant populations in conflict situations. Medicine, Conflict and Survival 17(1): 6-16.

2. Coupland RM, Meddings DR (1999) Mortality associated with use of weapons in armed conflicts, wartime atrocities, and civilian mass shootings: literature review. BMJ 319(7207): 407-410.

3. Levy BS, Sidel VW (2007) War and public health, Oxford University Press, UK.

4. Karakuş A, Yengil E, Akkücük S, Cevik C, Zeren C, et al. (2013) The reflection of the Syrian civil war on the emergency department and assessment of hospital costs. Ulus Travma Acil Cerrahi Derg 19(5): 429433.

5. Husum H (1947) War surgery. Neighalam publishing, Tehran, Iran.

6. DePalma RG, Burris DG, Champion HR, Hodgson MJ (2005) Blast injuries. New England Journal of Medicine 352(13): 1335-1342.

7. Mohebbi H (2007) Survey of injuries due to bullet and fragmentation munitions according to files of supreme medical commission. Journal Mil Med 9(3): 225-231.

8. Erhan E, Çorbacıoğlu ŞK, Güler S, Aslan Ș, Seviner M, et al. (2017) Analyses of demographical and injury characteristics of adult and pediatric patients injured in Syrian civil war. The American journal of emergency medicine 35(1): 82-86.

9. Owens BD, Kragh JF, Macaitis J, Svoboda SJ, Wenke JC (2007) Characterization of extremity wounds in operation Iraqi freedom and operation enduring freedom. Journal of Orthopaedic Trauma 21(4): 254-257.

10. Stanjner I, Petr C (1996) External fixator in the treatment of war bone fractures. Croatian Medical Journal 37: 165-168.

11. Harris AR (2002) Murder and medicine: the lethality of criminal assault 1960-1999. Homicide studies 6(2): 128-166.

12. Stansbury LG, Lalliss SJ, Branstetter JG, Bagg MR, Holcomb JB (2008) Amputations in US military personnel in the current conflicts in Afghanistan and Iraq. Journal of orthopaedic trauma 22(1): 43-46.

13. Reister F (1973) Battle casualties and medical statistics: U.S. army experience in the Korean War. The Surgeon General, Department of the Army, Washington DC, USA.

14. Beebe GW, DeBakey M (1952) Location of hits and wounds. In: Thomas CC (Ed.), Battle Casualties, Springfield, USA., pp. 165-205.

15. Husar J (1993) Modile surgical team in croatian Special forces units. Croatian medical journal 34: 276-279.

16. Champion HR (2003) A profile of combat injury. J Trauma 54(5): S13-S19.

17. Hardaway R (1978) Viet Nam wound analysis. J Trauma 18(9): 635-643.

18. Whelan TJ (1975) Surgical lessons learned and relearned in Vietnam. Surg Annu 7: 1-23.

19. Pear R (2004) U.S. has contingency plans for a draft of medical workers. New York Times, USA, A22. 


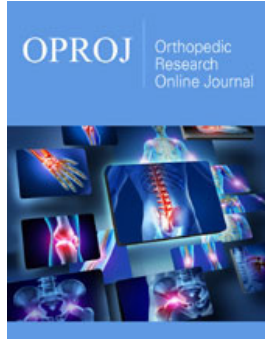

Orthopedic Research Online Journal

\section{Benefits of Publishing with us}

- High-level peer review and editorial services

- Freely accessible online immediately upon publication

- Authors retain the copyright to their work

- Licensing it under a Creative Commons license

- Visibility through different online platforms 